\title{
Rевевсн автісів: Evaluation of artificial neural network and regression PTFs in estimation soil hydraulic properties
}

\author{
口. BALATHANDAYUTHAM, A. VALLIAMMAI AND M. KRISHNAVENI
}

Article Chronicle : Received :

14.07.2017;

Accepted :

29.07.2017

\section{Key Words:}

Artificial neural network, Field capacity, Permanent wilting point, Pedotransfer functions
SUMMARY : Study of soil properties like field capacity (F.C.) and permanent wilting point (P.W.P.) play important roles in study of soil moisture retention curve. Although these parameters can be measured directly, their measurement is difficult and expensive. Pedotransfer functions (PTFs) provide an alternative by estimating soil parameters from more readily available soil data. Forty five different sampling locations in Sindapalli Uppodai were selected and undisturbed samples were taken to measure the water content at field capacity (FC), $-33 \mathrm{kPa}$, and permanent wilting point (PWP), $-1500 \mathrm{kPa}$. Measured soil variables included texture, organic carbon, water percentage at field capacity and wilting point, water saturation percentage, Bulk density were also determined for each soil sample at each location. Three different techniques including pattern recognition approach Artificial Neural Network (ANN), pedo transfer functions (PTF) and field measurement were used to predict the soil water at each sampling location. Root mean square error (RMSE), mean error (ME) and co-efficient of determination $\left(R^{2}\right)$ were used to evaluate the performance of all the three approaches. Our results showed that field measurement and PTF performed better than ANN in prediction of water content at both FC and PWP matric potential. Various statistics criteria for simulation performance also indicated that between field measurement and PTF, the former, predicted water content at PWP more accurate than PTF; however, both approach showed a similar accuracy to predict water content at FC.

How to cite this article : Balathandayutham, K., Valliammai, A. and Krishnaveni, M. (2017). Evaluation of artificial neural network and regression PTFs in estimation soil hydraulic properties. Agric. Update, 12 (TECHSEAR-4): 1105-1112; DOI: 10.15740/HAS/AU/12.TECHSEAR (4)2017/1105-1112.
Author for correspondence :

\section{K.}

BALATHANDAYUTHAM

Department of

Agronomy, Pandit

Jawaharlal Nehru College

of Agriculture and

Research Institute,

KARAIKAL

(PUDUCHERRY) INDIA

Email:balathandayutham

03@gmail.com

See end of the article for

authors' affiliations 